\title{
Induction of Protective Immunity against Experimental Eimeria tenella Infection using Serum Exosomes
}

\author{
Emilio del Cacho ${ }^{\mathrm{a}, *}$, Margarita Gallego ${ }^{\mathrm{a}}$, Hyun Soon Lillehoj ${ }^{\mathrm{b}}$, Joaquin Quilez ${ }^{\mathrm{a}}$, \\ Erik P. Lillehoj ${ }^{\mathrm{c}}$, Caridad Sánchez-Acedo ${ }^{\mathrm{a}}$
}

${ }^{\mathrm{a}}$ Department of Animal Pathology, Faculty of Veterinary Sciences, University of Zaragoza, Zaragoza, Spain

${ }^{\mathrm{b}}$ Animal Parasitic Diseases Laboratory, Animal and Natural Resources Institute, Agricultural Research Service, U.S. Department of Agriculture, Beltsville, MD, 20705, USA

${ }^{\mathrm{c}}$ Department of Pediatrics, University of Maryland School of Medicine, Baltimore, MD 21201, USA

Running Title: Protective immunity against Eimeria using serum exosomes

Keywords: chicken, dendritic cell, serum exosome, Eimeria tenella, immunity

*Corresponding author: Parasitología y Enfermedades Parasitarias, Facultad deVeterinaria, Miguel Servet 177, 50013-Zaragoza, Spain

Tel.: +349767615 56; Fax: +34976761612

E-mail: edelcach@unizar.es (E.del Cacho) 


\section{Abstract}

Avian coccidiosis is caused by Eimeria, a unicellular, apicomplexan protist which primarily infects intestinal epithelia resulting in nutrition malabsorption and reduced growth of commercial poultry. Vaccination of chickens with exosomes isolated from antigen presenting cells and containing parasite antigens (Ags) represents a promising alternative strategy to control avian coccidiosis, but is restricted in its commercial application due to limitations on production scale-up for mass immunization programs. Here, we report the biochemical and physiologic characteristics of exosomes derived from serum of E. tenella-infected chickens and their feasibility for inducing protective immunity to experimental coccidiosis. Exosomes isolated from the serum of E. tenella-infected chickens contained a subset of protein Ags found in the intact parasite. Serum-derived exosomes containing these E. tenella Ags localized to the intestine and spleen following intramuscular injection into naïve chickens. In vitro ELISPOT assays revealed increased numbers of IL-2-, IL-4-, IL-6-, and IFN- $\gamma$-secreting cells in the intestine and spleen of exosome-administered chickens, compared with vehicle controls. Pre-immunization of chickens with serum exosomes from E. tenella-infected chickens increased both body weight gain and feed conversion efficiency, and reduced both fecal parasite shedding and gut lesion scores following parasite infection, compared with vehicle controls. Finally, immunization with $\mathrm{CD} 80^{+}$serum exosomes stimulated greater numbers of cytokine-producing cells, and higher levels of protective immunity to E. tenella infection, compared with $\mathrm{CD}^{-} 0^{-}$exosomes. These results suggest the possibility of producing an effective, parasite-free vaccine against avian coccidiosis under field conditions using serum-derived $\mathrm{CD}^{+} 0^{+}$exosomes containing parasite Ags. 


\section{Introduction}

Eimeria is the etiologic agent of avian coccidiosis, a major parasitic disease of poultry that is indigenous to most regions of the world (Dalloul and Lillehoj, 2006). Infection by coccidial parasites has an enormous impact on worldwide poultry production due to the morbidity, mortality, and reduced body weight gain that the infection produces. Conventional disease control methods have relied on prophylactic administration of drugs with anticoccidial activity. However, alternative methods of disease mitigation are needed due to increasing government restrictions on the use of coccidiostats, the high costs of new drug development, and the emergence of drug-resistant parasites (Landman and Peek, 2005). Vaccination with live attenuated parasites is a practical alternative to drugs for coccidiosis control. However, vaccination is limited by the lack of cross-protection against Eimeria species absent in the vaccine formulation. Consequently, there is an urgent need to develop a field vaccine against avian coccidiosis that is safe and effective against all relevant parasites.

Exosomes are cell-derived, phospholipid-enclosed vesicles less than $100 \mathrm{~nm}$ in diameter released into the extracellular milieu that can be taken up by recipient cells at sites distal to their release. Exosomes from different cellular sources contain proteins specific for their cell type of origin, and these proteins, as well as those of their target cells, mediate exosome uptake (Théry et al., 2002). Exosomes secreted from antigen-presenting cells (APCs) play a functional role in mediating innate and adaptive immune responses to microbial pathogens (Moll, 2003), and recent reports suggest that such an exosome-based approach may be feasible for immunization against infections by Toxoplasma gondii (Beauvillain et al., 2007), Leishmania major (Schnitzer et al., 2010), Mycobacterium tuberculosis (Bhatnagar et al., 2007), and Salmonella enterica serovar Typhimurium 
(Bhatnagar et al., 2007). Dendritic cell (DC)-derived exosomes expressing major histocompatibility complex class I (MHC-I) and MHC-II molecules induce and enhance antigen (Ag)-specific T cell responses in vitro and in vivo (Denzer et al., 2000). DC-derived exosomes also express on their surface co-stimulatory molecules, such as CD80, necessary for Ag presentation (Clayton et al., 2001; Lamparski et al., 2002; Viaud et al., 2010).

Our previous work demonstrated a potent $\mathrm{T}$ cell-dependent protective immune response against Eimeria tenella, E. maxima, and E. acervulina infection of chickens following in vivo administration of exosomes isolated from DCs of the intestinal cecal tonsils and pulsed in vitro with soluble Eimeria Ags (del Cacho et al., 2012). Current technologies, however, limit the practicality of isolating chicken DCs exosomes on a scale sufficient for mass vaccination against avian coccidiosis in the field. Alternatively, exosomes from serum might constitute a more convenient source for such an application. It is well known that exosomes not only act locally, as it is the case in cecal tonsils during coccidiosis, but also circulate systemically through the vasculature and lymphoid systems (Caby et al., 2005). Highly purified exosomes can be isolated from serum with high efficiency and reproducibility, and relatively nominal cost compared with cellular sources. Therefore, this

study was designed to investigate the feasibility of isolating exosomes from serum of chickens infected with E. tenella for conferring protective immunity against experimental avian coccidiosis.

\section{Materials and Methods}

Animals. Cobb 500 broilers (Grupo Sada, Zaragoza, Spain) were hatched and reared under Eimeria-free conditions, with access to feed and water provided ad libitum. All 
experiments were performed in accordance with the guidelines approved by the University of Zaragoza Institutional Animal Care and Use Committee.

Parasites. The Houghton strain of E. tenella was kindly provided by Dr. R. Marshall (Veterinary Laboratories Agency, Weybridge, UK). Oocysts were propagated, isolated, and sporulated using standard procedures (Raether et al., 1991). Sporulated oocysts stored less than 4 weeks were used for infection.

Purification of $\mathrm{CD80}^{+}$and $\mathrm{CD80}^{-}$exosomes. Fifty chickens received 3 successive oral doses of $1.5 \times 10^{4}$ E. tenella oocysts each, given on days 10, 20, and 30 after hatching. At 10 days following the third inoculation, blood was collected from the brachial vein of each chicken, and serum was separated from clotted blood and pooled. Exosomes were isolated using the Total Exosome Isolation Reagent (from serum) (Life Technologies, Carlsbad, CA) according to the manufacturer's guidelines. $\mathrm{CD} 80^{+}$and $\mathrm{CD} 80^{-}$exosomes were separated using magnetic beads coated with the anti-chicken CD80 antibody (Ab) (Life Technologies) as described (Lee et al., 2011).

Western blot analysis. Exosomes were sonicated and centrifuged at 100,000 x g for $20 \mathrm{~min}$, the pellets were dissolved in reducing SDS-PAGE sample buffer, and proteins were resolved on a discontinuous gel system using standard protocols (Laemmli, 1970). Proteins were electrophoretically transferred to nitrocellulose at room temperature for $18 \mathrm{~h}$ at $40 \mathrm{mV}$. The membrane was blocked in PBS containing 4\% non-fat dry milk and incubated with rabbit anti-E. tenella polyclonal Ab (1:100) (del Cacho et al., 2009) or mouse anti-chicken CD80 monoclonal $\mathrm{Ab}(1: 100)$ (Lee et al., 2011) for $1 \mathrm{~h}$ at room temperature. Immunoblots were 
developed with peroxidase-conjugated goat anti-rabbit IgG or goat anti-mouse IgG secondary Abs and diaminobenzidine substrate.

Exosome immunization. One-day-old chickens $(n=224)$ were distributed into 4 groups of 56 chickens each ( 7 cages/group, 8 birds/cage) based on body weight. Treatment groups were randomly assigned using Microsoft Excel 2007. At $7 \mathrm{~d}$ of age, chickens in groups 1 and 2 were injected intramuscularly (i.m.) with $100 \mu \mathrm{l}$ of sterile PBS alone, and chickens in groups 3 and 4 were injected i.m. with $10 \mu \mathrm{g} / \mathrm{bird}$ of $\mathrm{CD}^{+} 0^{+}$or $\mathrm{CD}^{-} 0^{-}$serum exosomes from E. tenella-infected birds in $100 \mu \mathrm{l}$ of sterile PBS, respectively.

Eimeria Ag immunofluorescence in tissue sections. At $8 \mathrm{~d}$ post-immunization with exosomes, 6 chickens from each of the 4 treatment groups were euthanatized, and cecal tonsils (CT) and spleens were harvested and snap frozen in liquid nitrogen. Cryostat tissue sections were blocked with normal horse serum for $10 \mathrm{~min}$, followed by sequential incubations with rabbit anti-E. tenella $\mathrm{Ab}$ (del Cacho et al., 2009) (1:100) for $18 \mathrm{~h}$ at $4^{\circ} \mathrm{C}$ and Alexa Fluor 350-conjugated goat anti-rabbit IgG secondary Ab for 30 min (Molecular Probes, Eugene, OR). Nuclei were stained with mouse anti-DNA Ab (Santa Cruz Biotechnology, CA) followed by fluorescein-conjugated goat anti-mouse IgG secondary Ab for $30 \mathrm{~min}$ (Vector Laboratories, Burlingame, CA). As a negative control, tissue sections were stained with normal rabbit serum.

ELISPOT quantification of cytokine-secreting cells. CT and spleens were harvested at $8 \mathrm{~d}$ post-immunization with exosomes, pressed through a $250 \mu \mathrm{m}$ mesh screen, and washed in GKN buffer $(1.0 \mathrm{mg} / \mathrm{ml}$ glucose, $0.4 \mathrm{mg} / \mathrm{ml} \mathrm{KCl}, 8.0 \mathrm{mg} / \mathrm{ml} \mathrm{NaCl}, 0.35 \mathrm{mg} / \mathrm{ml}$ $\mathrm{NaHCO}_{3}$ ) containing $5.0 \mathrm{mM}$ EDTA. Single cell suspensions were obtained by filtering 
through a $70 \mu \mathrm{m}$ cell strainer (BD Falcon, Franklin Lakes, NJ) and were purified from dead cells, erythrocytes, and epithelial cells by Percoll density gradient centrifugation $(1.075 \mathrm{~g} / \mathrm{ml}$, high density; Amersham Pharmacia Biotech, Uppsala, Sweden) at 950 x g for 20 min. Since Cobb chickens are allogenic, quantification of cytokine-producing cells was performed by culturing $1.0 \times 10^{5}$ cells from individual chicken in the absence or presence of $100 \mu \mathrm{g} / \mathrm{ml}$ of E. tenella Ag in 96-well microplates with $0.2 \mathrm{ml}$ of RPMI 1640 medium for $3 \mathrm{~d}$ (del Cacho et al., 2011). For ELISPOT assays, microtiter plates were coated overnight at $4^{\circ} \mathrm{C}$ anti-chicken IL-2, IL-4, IL-6, or IFN- $\gamma$ Abs, blocked with $10 \mu \mathrm{g} / \mathrm{ml}$ of PBS containing $2 \%$ bovine serum albumin and $0.05 \%$ Tween 20 (PBS/BSA/T) at room temperature for $2 \mathrm{~h}$, and washed 3 times with PBS. The cells were added to Ab-coated microplates and ELISPOT assays were performed as described (del Cacho et al., 2011).

In vivo protection against $\boldsymbol{E}$. tenella infection. At $8 \mathrm{~d}$ post-immunization with $\mathrm{CD}^{+} 0^{+}$or $\mathrm{CD}^{-} 0^{-}$serum exosomes from E. tenella-infected birds (groups 3 and 4), or PBS control (groups 1 and 2), chickens in groups 2, 3 and 4 were infected by oral gavage with a single dose of $1.0 \times 10^{4}$ sporulated oocysts of E. tenella and chickens in group 1 were given PBS alone. Body weight gains and feed conversion ratios were measured at 0 and $10 \mathrm{~d}$ postinfection as described (del Cacho et al., 2009) (Fig. 1). Fecal oocyst shedding was measured between 5 and 10 d post-infection as described (Lee et al., 2007). At 6 d post-infection, intestinal lesion scores were determined on a graded scale from 0 (none) to 4 (high) in a blinded fashion by 2 independent observers as described (Johnson and Reid, 1970). The percent mortality in all groups was recorded at $10 \mathrm{~d}$ post-infection.

Statistical analysis. All data were expressed as mean \pm standard deviation (SD) values. Duncan's multiple-range test was used to evaluate the differences between treatment 
groups. Differences between mean values were considered statistically significant at $P<$ 0.05 .

\section{Results}

CD80 and Eimeria Ag expression by serum exosomes. Immunoblot analysis of total proteins from $\mathrm{CD} 80^{+}$exosomes using an anti-chicken $\mathrm{CD} 80 \mathrm{Ab}$ revealed a band with an apparent molecular weight of $35.0 \mathrm{kDa}$, identical to that reported for chicken CD80 (Lee et al., 2011) (Fig. 2). A similar protein band was not detected using CD80- exosomes (Fig. 2). Immunoblot analysis using an anti-E. tenella rabbit $\mathrm{Ab}$ revealed an identical pattern of 3 protein bands with apparent molecular weights between 42.0 and $55.0 \mathrm{kDa}$ in both CD80 ${ }^{+}$ and $\mathrm{CD} 80^{-}$serum exosomes isolated from E. tenella-infected chickens (Fig. 3) However, not all of the protein bands identified in E. tenella sporozoites were seen in either of the exosomes (Fig. 3).

Immunofluorescence localization of E. tenella Ags in tissue sections. E. tenella Ags in cells morphologically resembling follicular dendritic cells (FDCs) in the intestinal CT and spleen were seen in chickens immunized with $\mathrm{CD}^{+} 0^{+}$serum exosomes from E. tenellainfected chickens by immunofluorescence microscopy (Figs. 4A, 4C). Immunization of chickens with $\mathrm{CD} 80^{-}$exosomes did not reveal Ag-containing cells in the CT or spleen (Figs. 4B, 4D).

Ag-stimulated cytokine-producing cells. Immunization of chickens with $\mathrm{CD} 80^{+}$or $\mathrm{CD}^{-}$serum exosomes increased the number of IL-2-, IL-4, IL-6-, and IFN- $\gamma$-producing cells in the CT and spleen compared with unimmunized chickens (Fig. 5). While the numbers of IL4- and IL6-producing cells were identical following immunization with either $\mathrm{CD}^{+} 0^{+}$or 
$\mathrm{CD}^{-} 0^{-}$exosomes, chickens immunized with $\mathrm{CD} 80^{+}$exosomes had increased numbers of IL2- and IFN- $\gamma$-producing cells compared with birds immunized with CD80- exosomes.

In vivo protection against $\boldsymbol{E}$. tenella infection. Chickens immunized with $\mathrm{CD} 80^{+}$ (group 3) or $\mathrm{CD}^{-} 0^{-}$(group 4) serum exosomes isolated from E. tenella-infected chickens and subsequently infected with E. tenella had increased body weight gains, reduced feed conversion ratios, diminished fecal oocyst shedding, and decreased intestinal lesion scores, compared with the unimmunized and infected controls (group 2) (Table I). Additionally, $\mathrm{CD}^{+} 0^{+}$group 3 chickens had greater body weight gains as well as decreased feed conversion ratios, fecal oocyst shedding, and intestinal lesion scores, compared with $\mathrm{CD}^{-} 0^{-}$group 4 animals. These results indicate that while immunization with either type of exosomes induces a protective immune response against E. tenella infection, a more robust immunity was generated against the parasite following immunization with $\mathrm{CD} 80^{+}$exosomes, compared with CD80- exosomes.

\section{Discussion}

This study demonstrates that serum-derived exosomes from E. tenella-infected chickens express a subset of protein antigens present in the intact parasite, and that $\mathrm{CD}^{\circ} 0^{+}$, but not $\mathrm{CD}^{-} 0^{-}$, exosomes localize to the intestinal CT and spleen following i.m. injection into naïve chickens. Immunization of chickens with serum exosomes increased the numbers of IL-2-, IL-4, IL-6-, and IFN- $\gamma$-producing cells in the CT and spleen in response to E. tenella Ag exposure, compared with unimmunized chickens. Finally, $\mathrm{CD} 80^{+}$serum exosomes induced greater numbers of IL-2- and IFN- $\gamma$-secreting CT and spleen cells, and stimulated greater protective immunity to E. tenella challenge infection, compared with $\mathrm{CD}^{-} 0^{-}$exosomes. Our previous studies demonstrated successful vaccination against avian coccidiosis using DC- 
derived exosomes incubated with Eimeria Ags (del Cacho et al., 2012). The current study now extends this vaccination strategy to serum exosomes, which when compared with cellderived exosomes, potentially offers the advantages of reduced vaccine production costs and decreased manufacturing complexity.

Exosomes were initially described as a relatively homogeneous population of vesicles with diameters of 40-90 nm by electron microscopy (Raposo et al., 1996). Exosomes have been extensively studied for their contributions to physiology, immunity, cancer, and intercellular communication, revealing an impressive diversity of fuctions depending on their cellular source. Ultrastructural, Western blot, and mass spectrometry analyses have identified distinct subsets of exosomal proteins between different cell types (Graner et al., 2009; Ataya et al., 2011), which may explain their functional diversity. The current study demonstrated both $\mathrm{CD}^{+} 0^{+}$and $\mathrm{CD}^{-} 0^{-}$exosomes in the serum of chickens infected with E. tenella. Mammalian CD80 has been reported to be a specific marker of APC-derived exosomes (Raposo et al., 1996; Zitvogel et al., 1998; Clayton et al., 2001). The majority of CD80exosomes appear to be released from cells which do not have a role in the immune response (Ataya et al., 2011; Heijnen et al., 1999; Zhang and Grizzle, 2014). However, CD80exosomes released from the basolateral membrane of intestinal epithelial cells reportedly function in $\mathrm{Ag}$ transport, leading to either the induction of tolerance under noninflammatory conditions (Van Neil et al., 2001) or Ag-specific immunity under inflammatory conditions (Van Niel et al., 2003). Therefore, similar to $\mathrm{CD}^{+} 0^{+}$exosomes, some CD80- exosomes are capable of transfering foreign Ags to intestinal DCs (Andre et al., 2004; Van Niel et al., 2003) for presentation to mucosal $\mathrm{T}$ lymphocytes to activate local and systemic immune responses (Skokos et al., 2003; Morelli et al., 2015). Considering the high degree of tissue trophism of E. tenella for the intestinal caecum of chickens, our results suggest that CD80- 
exosomes containing parasite Ags are released from infected cecal epithelial cells and contribute, at least in part, to the host immune response against parasite infection.

Naïve chickens immunized with either $\mathrm{CD}^{+} 0^{+}$or $\mathrm{CD}^{-}$serum exosomes had increased numbers of intestinal and spleen cells secreting Th1 (IL-2, IL-6, IFN- $\gamma$ ) and Th2 (IL-4) cytokines, compared with unimmunized controls. However, compared with chickens immunized with $\mathrm{CD}^{-}$exosomes, CD80-immunized birds had (1) increased numbers of IL2- and IFN- $\gamma$-producing gut and spleen cells, (2) greater localization in the the CT and spleen, and (3) greater protective immunity following E. tenella infection, as measured by weight gain, feed efficiency, parasite shedding, and intestinal lesions. Given that localization of foreign Ags in FDCs has been associated with the induction of immunological memory (Szakal et al., 1989; Gallego et al., 1995; Banchereau and Steinman, 1998), taken together these findings suggest that immunization of chickens with $\mathrm{CD}^{+} 0^{+}$exosomes containing parasite Ags not only may be more efficient in conferring protection against parasite infection, but also may extend immunological memory to subsequent re-infection, compared with CD80- exosomes.

\section{Acknowledgments}

This investigation was partially funded by Grant A46 from the Research Council of Aragón (Spain) and USDA-CSREES proposal 2005-01812 (US Veterinary Immune Reagent Network). 


\section{References}

Andre, F., Chaput, N., Schartz, N.E.C., Flament, C., Aubert, N., Bernard, J., Lemonnier, F., Raposo, G., Escudier, B., Hsu, D.H., Tursz, T., Amigorena, S., Angevin, E., Zitvogel, L., 2004. Exosomes as potent cell-free peptide-based vaccine. I: Dendritic cell-derived exosomes transfer functional MHC class I/peptide complexes to dendritic cells. Blood 172, 2126-2136.

Ataya, S., Gercel-Taylorb, C., Kesimerc, M., Taylor. D.D., 2011. Morphologic and proteomic characterization of exosomes released by cultured extravillous trophoblast cells. Exp. Cell Res. 317, 1192-1202.

Banchereau, J., Steinman, R.M., 1998. Dendritic cells and the control of immunity. Nature $392,245-252$.

Beauvillain, C., Ruiz, S., Guiton, R., Bout, D., Dimier-Poisson, I., 2007. A vaccine based on exosomes secreted by a dendritic cell line confers protection against $T$. gondii infection in syngeneic and allogeneic mice. Microbes Infect. 9, 1614-1622.

Bhatnagar, S., Shinagawa, K., Castellino, F.J., Schorey, J.S., 2007. Exosomes released from macrophages infected with intracellular pathogens stimulate a proinflammatory response in vitro and in vivo. Blood 110, 3234-3244.

Caby, M.P., Lankar, D., Vincendeau-Scherrer, C., Raposo, G., Bonnerot, C., 2005. Exosomal-like vesicles are present in human blood plasma. Int. Immunol. 17, 879-887. 
Clayton, A., Court, J., Navabi, H., Adams, M., Mason, M.D., Hobot, J.A., Newman, G.R., Jasani, B., 2001. Analysis of Ag-presenting-cell-derived exosomes, based on immunomagnetic isolation and flow cytometry. J. Immunol. Methods 247, 163-174.

Dalloul, R.A., Lillehoj, H.S., 2006. Poultry coccidiosis: Recent advancements in control measures and vaccine development. Expert Rev. Vaccines 5, 143-163.

Denzer, K., van Eijk, M., Kleijmeer, M.J., Jakobson, E., Groot, C., Geuze, H.J., 2000. Follicular dendritic cells carry MHC class II-expressing microvesicles at their surface. J. Immunol. 165, 1259-1265.

del Cacho, E., Gallego, M., Lillehoj, H.S., López-Bernard, F., Sánchez-Acedo, C., 2009. Avian follicular and interdigitating dendritic cells: isolation and morphologic, phenotypic, and functional analyses. Vet. Immunol. Immunopathol.129, 66-75.

del Cacho, E., Gallego, M., Lee, S., Lillehoj, H.S., Quilez, J., Lillehoj, E., Sánchez-Acedo, C., 2011. Induction of protective immunity against Eimeria tenella infection using Ag-loaded dendritic cells (DC) and DC-derived exosomes. Vaccine 29, 3818-3825.

del Cacho, E., Gallego, M., Lee, S., Lillehoj, H., Quilez, J., Lillehoj, E., Sánchez-Acedo, C., 2012. Inductionof protective immunity against Eimeria tenella, Eimeria maxima, and Eimeria acervulina infections using dendritic cell-derived exosomes. Infect. Immun. 80, 1909-1916. 
Gallego, M., del Cacho, E., Zapata, A., Bascuas, J.A., 1995. Ultrastructural identification of the splenic follicular dendritic cells in the chicken. Anat. Rec. 242, 220-224.

Graner, M.W., Alzate, O., Dechkovskaia, A.M., Keene, J.D., Sampson, J.H., Mitchell, D.A., Bigner, D.D., 2009. Proteomic and immunologic analyses of brain tumor exosomes, FASEB J. 23, 1541-1557.

Heijnen, H.F.G., Schiel, A.E., Fijnheer, R., Geuze, H.J., Sixma. J.J., 1999. Activated platelets release two types of membrane vesicles: Microvesicles by surface shedding and exosomes derived from exocytosis of multivesicular bodies and $\alpha$-granules. Blood 94, 3791-3799.

Johnson, J., Reid, W.M., 1970. Anticoccidial drugs: Lesion scoring techniques in battery and floor-pen experiments with chickens. Exp. Parasitol. 28, 30-36.

Laemmli, U.K., 1970. Cleavage of structural proteins during the assembly of the head of bacteriophage T4. Nature 227, 680-685.

Lamparski, H.G., Metha-Damani, A., Yao, J.Y., Patel, S., Hsu, D.H., Ruegg, C., LePecq, J.B., 2002. Production and characterization of clinical grade exosomes derived from dendritic cells. J. Immunol. Methods 270, 211-226.

Landman, W.J.M., Peek, H.W., 2005. Anticoccidial sensitivity profiles of recently obtained Dutch, German and Spanish Eimeria spp. isolates. In: Proceedings of the IV International Poultry Symposium, Istanbul, Turkey. pp. 133-152. 
Lee, S.H., Lillehoj, H.S., Dalloul, R.A., Park, D.W., Hong, Y.H., Lin, J.J., 2007. Influence of Pediococcus-based probiotic on coccidiosis in broiler chickens. Poultr. Sci. 86, 63-66.

Lee, S.H., Lillehoj, H.S., Park, M.S., Lee, K.W., Baldwin, C., Tompkins, D., Wagner, B., del Cacho, E., Babue, U., Min, W., 2011. Development and characterization of mouse monoclonal antibodies reactive with chicken CD80. Comp. Immunol. Microbiol. Infect. Dis. 34, 273-279.

Moll, H., 2003. Dendritic cells as a tool to combat infectious diseases. Immunol. Lett. 85, $153-7$.

Morelli, A.E., Larregina, A.T., Shufesky, W.J., Sullivan, M.L.G., Stolz, D.B., Papwoth, G.D., Zahorchak, A.F., Logar, A.J., Wang, Z., Watkins, S.C., Falo Jr, L.D., Thomson, A.W., 2015. Endocytosis, intracellular sorting, and processing of exosomes by dendritic cells. Immunobiol. 28, 3257-3266.

Raether, W., Hofmann, J., Uphoff, M., Eckert, H.S., 1995. In vitro cultivation of avian Eimeria species: Eimeria tenella. In: Eckert, J., Braun, R., Shirley, M.W., Coudert, P. (Eds), Biotechnology. Guidelines on techniques in coccidiosis research. European Commission, Brussels, Belgium, pp. 79-84.

Raposo, G., Nijman, H.W., Stoorvogel, W., Liejendekker, R., Harding, C.V., Melief, C.J., Geuze, H.J., 1996. B lymphocytes secrete Ag-presenting vesicles. J. Exp. Med. 183, 11611172. 
Schnitzer, J.K., Berze,l S., Fajardo-Moser, M., Remer, K.A., Moll, H., 2010. Fragments of Ag-loaded dendritic cells (DC) and DC-derived exosomes induce protective immunity against Leishmania major. Vaccine 28, 5785-5793.

Skokos, D., Botros, H.G., Demeure, C., Morin, J., Peronet, R., Birkenmeier, G., Boudaly, S., Mécheri, S., 2003. Mast cell-derived exosomes induce phenotypic and functional maduration of dendritic cells and elicit specific immnune response in vivo. J. Immunol. 170, 3037-3045.

Szakal, A.K., Kosko, M.R.I., Tew, J.G., 1989. Microanatomy of lymphoid tissue during humoral immune response: Structure, function and relationships. Annu. Rev. Immunol. 7, 91109.

Théry, C., Zitvogel, L., Amigorena, S., 2002. Exosomes: Composition, biogenesis and function. Nat. Rev. Immunol. 2, 569-579.

Van Niel, G., Raposo, G., Candalh, C., Boussac, M., Hershberg, R., Cerf-Bensussan, N., Heyman, M., 2001. Intestinal epithelial cells secrete exosome-like vesicles. Gastroenterology $121,337-349$.

Van Niel, G., Mallegol, J., Bevilacqua, C., Candalh, C.,Brugière, S., Tomaskovic-Crook, E., Heath, J.K., Cerf-Bensussan, N., Heyman, M., 2003. Intestinal epithelial exosomes carry MHC class II/peptides able to inform the immune system in mice. Gut 52, 1690-1697. 
Viaud, S., Théry, C., Ploix, S., Tursz, T., Lapierre, V., Lantz, O., Zitvogel, L., Chaput, N., 2010. Dendritic cell-derived exosomes for cancer immunotherapy: What's next? Cancer Res. $70,1281-1285$.

Zhang, H.G., Grizzle, W.E., 2014. A novel pathway of local and distant intercellular communication that facilitates the growth and metastasis of neoplastic lesions. Am. J. Pathol. $184,28-41$.

Zitvogel, L., Regnault, A., Lozier, A., Wolfers, J., Flament, C., Tenza, D., RicciardiCatsagnoli, P., Raposo,G., Amigorena, S., 1998. Erradication of established murine tumors using a novel cell-free vaccine: Dendritic cell-derived exosomes. Nat. Med. 4, 594-600. 


\section{Figure Legends}

Fig. 1. Schematic illustration of the experimental design. Chickens immunized with $\mathrm{CD}^{+} 0^{+}$or $\mathrm{CD}^{-}$serum-derived exosomes were used to assess E. tenella Ag localization and Agspecific immune response in the absence of parasite infection. Exosome-immunized and $E$. tenella-infected chickens were used to measure in vivo parameters of protection against $E$. tenella infection.

Fig. 2. Immunoblot analysis of serum-derived exosomes using anti-chicken CD80 Ab. Lane 1, prestained molecular weight marker proteins. Lane 2 , proteins extracted from $\mathrm{CD}^{+} 0^{+}$ serum exosomes. Lane 3, proteins extracted from $\mathrm{CD}^{-} 0^{-}$serum exosomes. Lane 4, proteins extracted from chicken intestinal DCs. Lane 5, proteins extracted from E. tenella sporozoites. Note the presence (lane 2) or absence (lane 3) of the $35.0 \mathrm{kDa}$ CD80 protein in serum exosomes isolated from chickens infected with three successive oral doses of $1.5 \times 10^{4} \mathrm{E}$. tenella oocysts that co-migrates with a similar protein in DCs (lane 4).

Fig. 3. Immunoblot analysis of serum-derived exosomes using rabbit anti-E. tenella Ab. Lane 1, prestained molecular weight marker proteins. Lane 2 , proteins extracted from $\mathrm{CD}^{+} 0^{+}$ serum exosomes. Lane 3, proteins extracted from $\mathrm{CD}^{-} 0^{-}$serum exosomes. Lane 4, proteins extracted from chicken intestinal DCs. Lane 5, proteins extracted from E. tenella sporozoites. Note the presence of E. tenella Ags in $\mathrm{CD}^{+}$(lane 2) and $\mathrm{CD}^{-} 0^{-}$(lane 3) serum exosomes isolated from chickens infected with three successive oral doses of $1.5 \times 10^{4}$ E. tenella oocysts that co-migrate with similar proteins in E. tenella sporozoites (lane 5).

Fig. 4. Immunofluorescence analysis of E. tenella Ag-binding cells in CT and spleen of E. tenella-immunized chickens. CT (A, B) and spleen (C, D) tissue sections were stained with 
rabbit anti-E. tenella $\mathrm{Ab}$ revealing parasite Ag-binding cells (blue) in sections from chickens immunized with $\mathrm{CD}^{+} 0^{+}$serum exosomes $(\mathrm{A}, \mathrm{C})$ or $\mathrm{CD}^{-} 0^{-}$serum exosomes $(\mathrm{B}, \mathrm{D})$. Note that only tissues from chickens immunized with $\mathrm{CD} 80^{+}$serum exosomes display Ag-binding cells (arrows) within germinal centers where the labelled cells form a dense network distributed within the entire germinal center.

Fig. 5. Cytokine secreting cells in nonimmunized chickens, or chickens immunized with $\mathrm{CD}^{-} 0^{-}$or $\mathrm{CD} 80^{+}$serum exosomes isolated from E. tenella-infected chickens. Eimeria Agstimulated IL-2-, IL-4-, IL-6-, and IFN- $\gamma$-secreting cells in the spleen (open bars) and CT (closed bars) were quantified by ELISPOT assay at 8 days following exosome immunization. Each bar represents the mean \pm SD value. Within each graph, bars with different letters are significantly different $(P<0.05)$ according to Duncan's multiple range test. 
TABLE 1. Effect of immunization with serum exosomes on in vivo parameters of protective immunity against Eimeria tenella.

\begin{tabular}{|c|c|c|c|c|c|}
\hline $\begin{array}{l}\text { Treatment } \\
\text { Group }\end{array}$ & $\begin{array}{l}\text { Body wt gain } \\
\text { (g/chicken) }\end{array}$ & $\begin{array}{l}\text { Feed conversion ratio } \\
\text { (g feed/g chicken) }\end{array}$ & $\begin{array}{l}\text { Fecal oocyst output } \times 10^{3} \\
\text { per chicken }\end{array}$ & $\begin{array}{l}\text { Lesion score } \\
\text { (scale of } 0-4 \text { ) }\end{array}$ & Mortality (\%) \\
\hline $\begin{array}{l}\text { Unimmunized, } \\
\text { Uninfected }\end{array}$ & $653 \pm 12^{\mathrm{a}}$ & $1.41 \pm 0.08^{\mathrm{a}}$ & $0^{\mathrm{a}}$ & $0^{\mathrm{a}}$ & $0^{\mathrm{a}}$ \\
\hline $\begin{array}{l}\text { Unimmunized, } \\
\text { Infected }\end{array}$ & $371 \pm 25^{\mathrm{b}}$ & $2.158 \pm 0.12^{\mathrm{b}}$ & $15,739 \pm 0.68^{b}$ & $2.7 \pm 0.6^{\mathrm{b}}$ & $16 \pm 5.6^{\mathrm{b}}$ \\
\hline $\begin{array}{l}\text { Immunized with } \\
\text { CD } 80^{+} \text {exosomes, } \\
\text { Infected }\end{array}$ & $649 \pm 18^{\mathrm{a}}$ & $1.45 \pm 0.09^{\mathrm{a}}$ & $302 \pm 0.71^{c}$ & $0.9 \pm 0.6^{\mathrm{c}}$ & $0^{\mathrm{a}}$ \\
\hline $\begin{array}{l}\text { Immunized with } \\
\text { CD80 exosomes, } \\
\text { Infected }\end{array}$ & $523 \pm 20^{\mathrm{c}}$ & $1.63 \pm 0.09^{\mathrm{c}}$ & $7,890 \pm 0.87^{\mathrm{d}}$ & $1.5 \pm 0.6^{\mathrm{d}}$ & $0^{\mathrm{a}}$ \\
\hline
\end{tabular}

Each value represents the mean $\pm \mathrm{SD}$ of seven cages per each treatment group ( 8 birds/cage). Within each group, values with different superscripts are significantly different $(\mathrm{p}<0.05)$ according to the Duncan's multiple range test. Lesion score ranges from 1 (none) to 4 (high) according to Jonson and Reid (1970). 


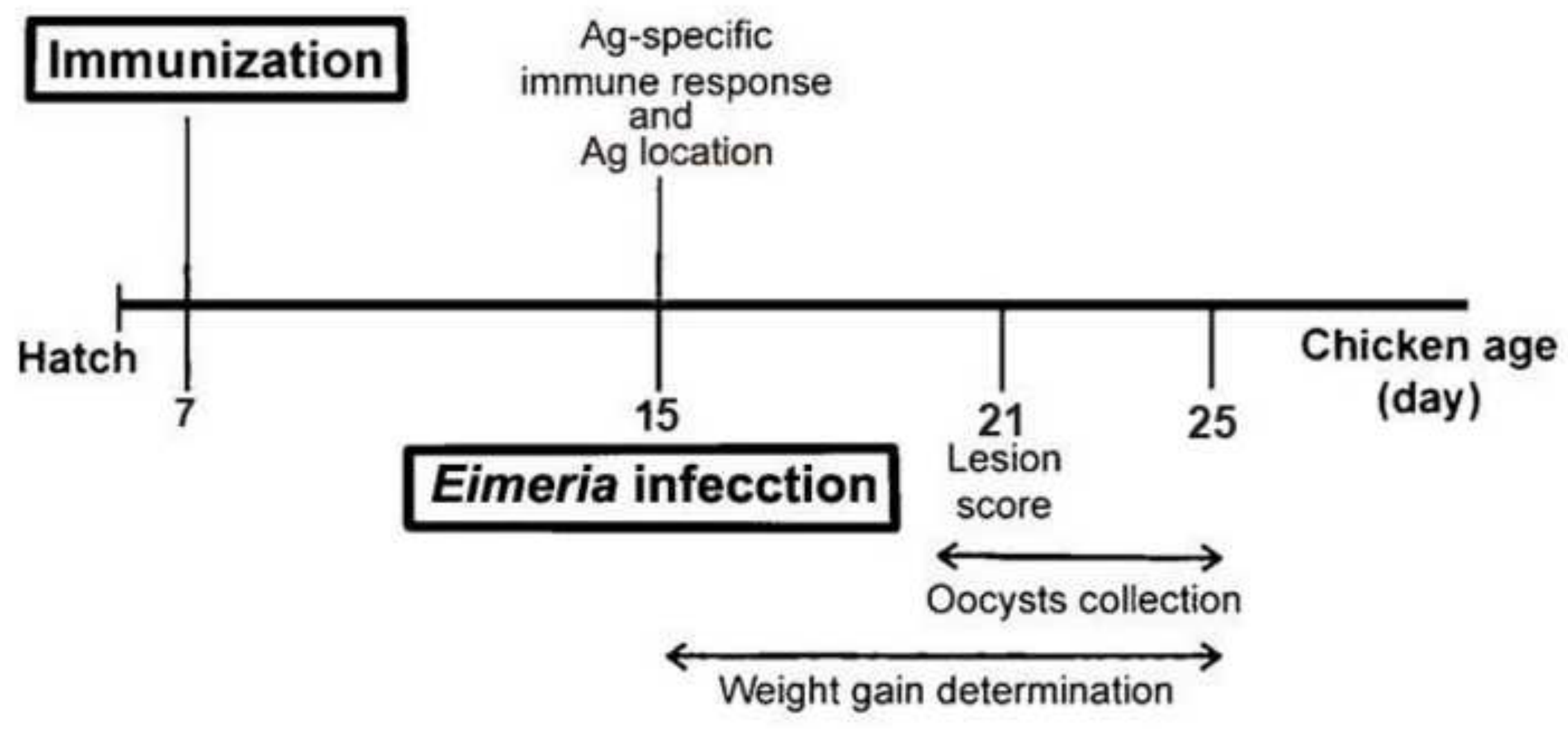


$66,000-$

55,000

45,000 -

36,000 29,000 -
24,000 $29,000-$
$24,000-$ 

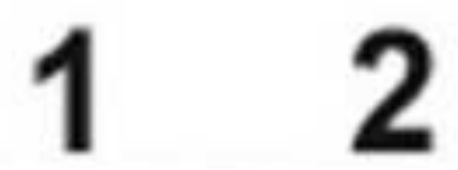

3

4

66,000

55,000 -

45,000 -

36,000

29,000 -

24,000 - 

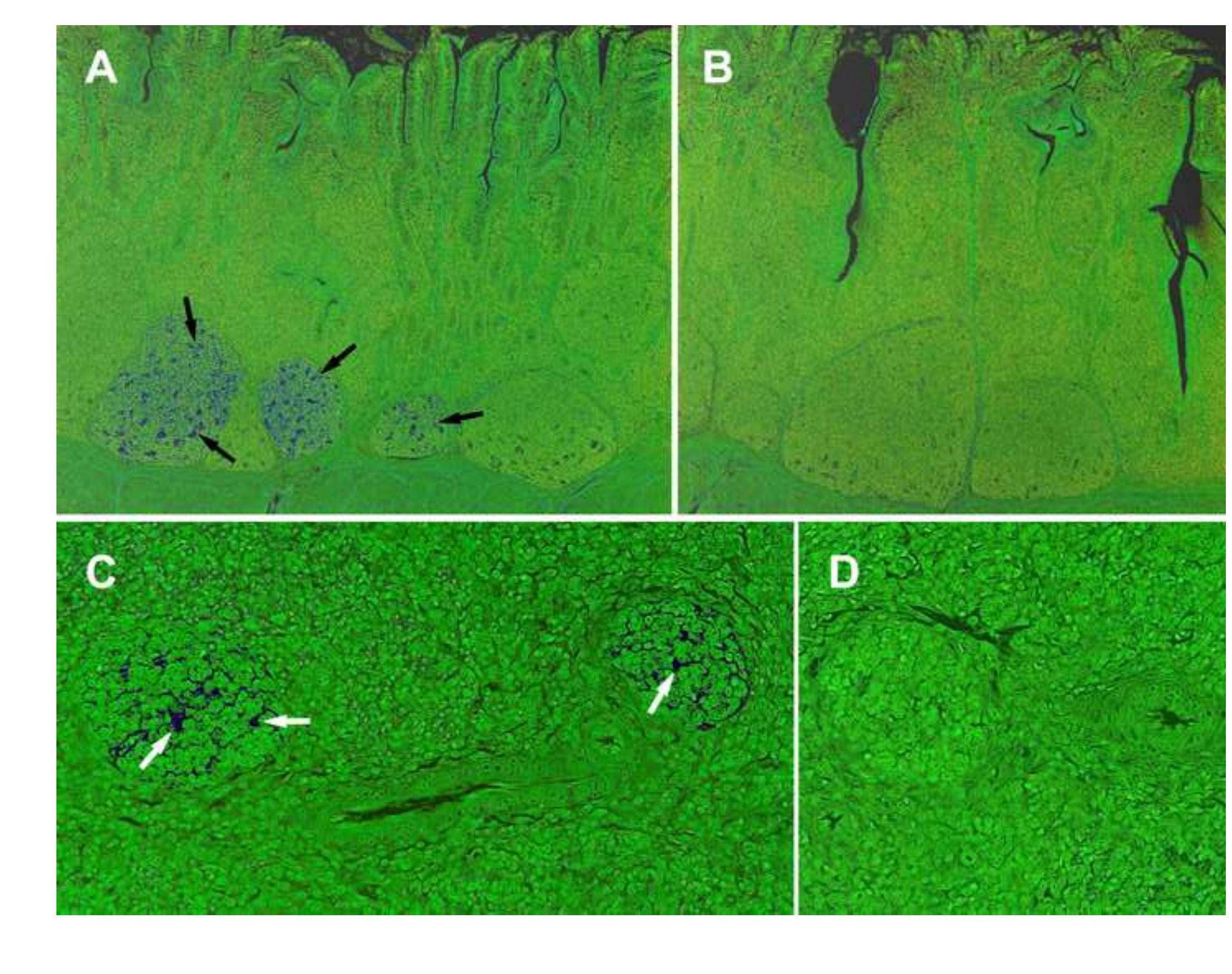

Figure 4

.
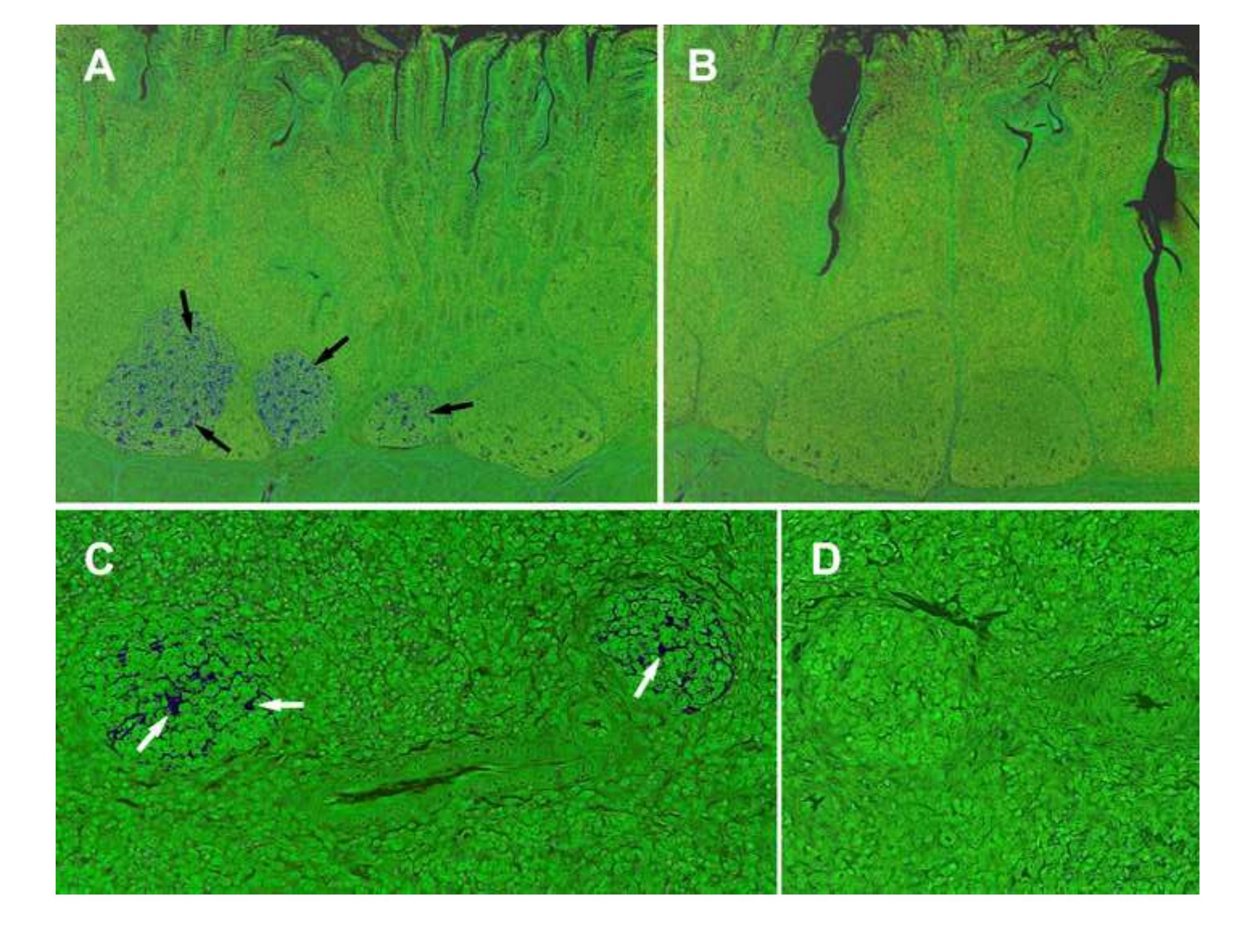

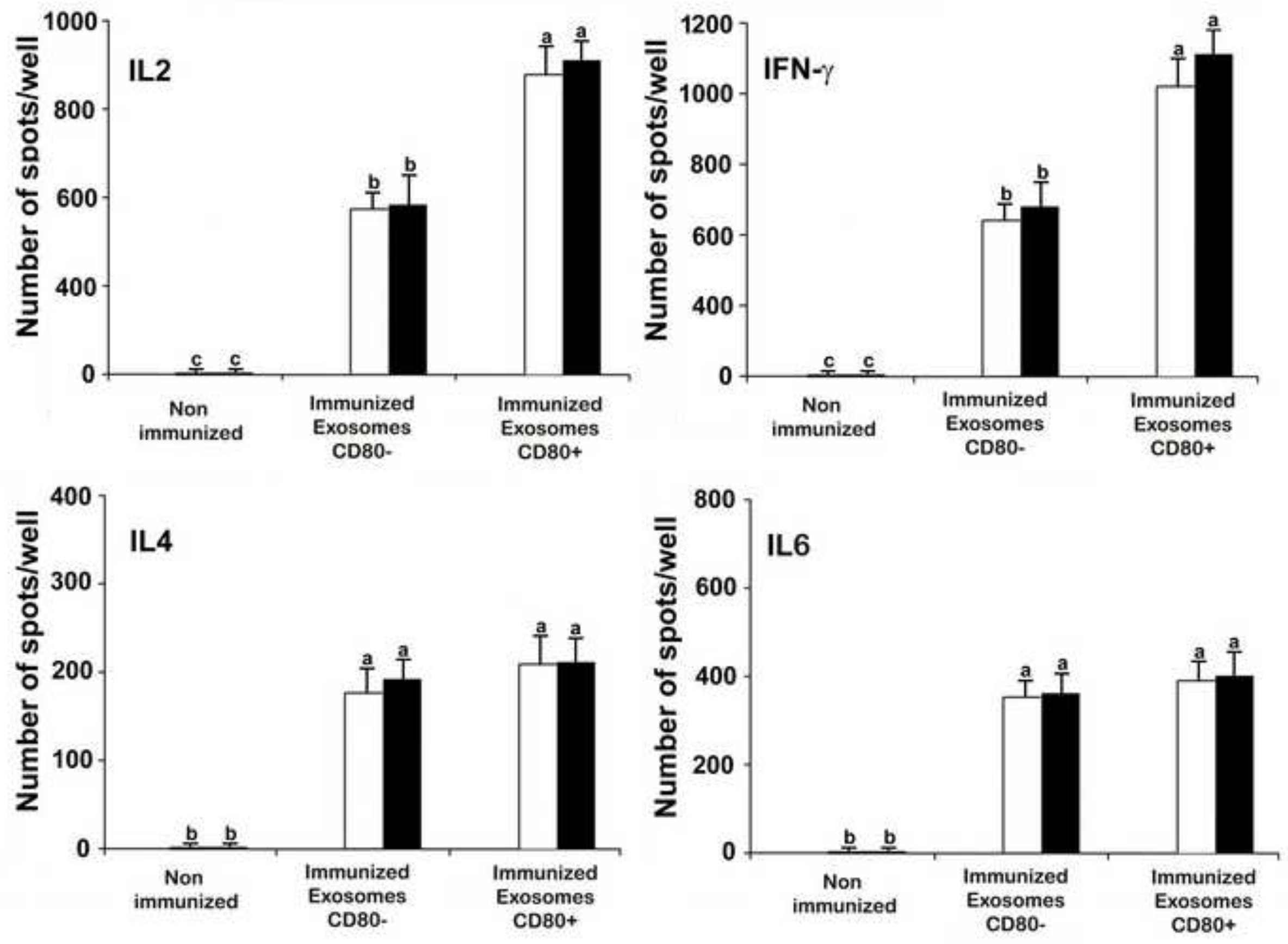